\title{
Growth and reproduction properties of endemic Capoeta kosswigi and Barbus ercisianus in the Deliçay Stream (Van, Turkey)
}

\section{Deliçay (Van, Türkiye)'da yaşayan endemik Capoeta kosswigi ve Barbus ercisianus'un büyüme ve üreme özellikleri}

\author{
Ataman Altuğ Atıcı $^{1 *}$ • Ahmet Sepil2 • Fazıl Şen ${ }^{3}$ • Asude Çavuş ${ }^{4}$ \\ 1 Van Yüzüncü YIl University, Faculty of Fisheries, Department of Basic Sciences, 65080, Tusba, Van, Turkey \\ 2 Van Yüzüncü Yıl University, Faculty of Fisheries, Department of Basic Sciences, 65080, Tusba, Van, Turkey \\ ${ }^{3}$ Van Yüzüncü Yıl University, Faculty of Fisheries, Department of Basic Sciences, 65080, Tusba, Van, Turkey \\ ${ }^{4}$ Van Yüzüncü YIl University, Faculty of Fisheries, Department of Basic Sciences, 65080, Tusba, Van, Turkey \\ (D) https://orcid.org/0000-0001-8700-8969 \\ (D) https://orcid.org/0000-0002-3201-5181 \\ (D) https://orcid.org/0000-0003-4242-3813 \\ (D) https://orcid.org/0000-0001-8328-4675
}

\section{How to cite this paper:}

Atıcl, A.A., Sepil, A., Şen, F. \& Çavuş, A. (2021). Growth and reproduction properties of endemic Capoeta kosswigi and Barbus ercisianus in the Deliçay Stream (Van, Turkey). Ege Journal of Fisheries and Aquatic Sciences, 38(3), 293-302. DOI: 10.12714/egejfas.38.3.05

Abstract: In this study, the growth and reproductive characteristics of Capoeta kosswigi Karaman, 1969 and Barbus ercisianus Karaman, 1971, which are endemic to the Lake Van Basin, in Deliçay (Van) were investigated. A total of 309 C. kosswigi and 288 B. ercisianus specimens were caught by electrofishing between April and August 2018. The fork length of C. kosswigi and B. ercisianus ranged from $3.7-26.1 \mathrm{~cm}$ and from $4.3-22.7 \mathrm{~cm}$, and the total weights ranged from 0.6-227.4 $\mathrm{g}$ and from 1.2-140.0 g, respectively. The most intensive catching was in C. kosswigi population of 5.0-6.9 $(27.5 \%) \mathrm{cm}$ and 0$19.9(67.0 \%) \mathrm{g}$ in the groups, and $12.0-13.9(24.7 \%) \mathrm{cm}$ and $0-9.9(23.3 \%) \mathrm{g}$ groups in B. ercisianus. Condition factor was determined as $1.305 \pm 0.008$ $(0.798-1.886)$ in C. kosswigi and 1.158 $\pm 0.006(0.864-1.559)$ in B. ercisianus. The length-weight relationships were calculated as $W=0.01435 \times L^{2.952}\left(r^{2}=\right.$ $0.996)$ for $C$. kosswigi and $W=0.01276 \times L^{2.959}\left(r^{2}=0.994\right)$ for $B$. ercisianus. The $M: F$ ratio was calculated as 1:0.15 in $C$. kosswigi and 1:0.64 in $B$. ercisianus. It was established that $C$. kosswigi attained sexual maturity when they reached to $11 \mathrm{~cm}$ fork length for males, $18 \mathrm{~cm}$ fork length for females. Maturation of B.ercisianus individuals occurred at $9 \mathrm{~cm}$ fork length in males and $12 \mathrm{~cm}$ fork length in females. The spawning in C. kosswigi was observed from $11^{\text {st }}$ week of May to $2^{\text {nd }}$ week of July, and in $B$. ercisianus from $11^{\text {st }}$ week of May to $1^{\text {st }}$ week of August. It may be suggested that minimum catching size must be $20 \mathrm{~cm}$ fork length for $C$. kosswigi and $15 \mathrm{~cm}$ fork length for $B$. ercisianus.

Keywords: Barbus ercisianus, Capoeta kosswigi, growth, length-weight relationships, reproduction

Öz: Bu çalışmada Van Gölü Havzasina endemik olan Capoeta kosswigi Karaman, 1969 ve Barbus ercisianus Karaman, 1971 türlerinin Deliçay (Van)'da büyüme ve üreme özellikleri arasstırımıștır. Nisan 2018 - Ağustos 2018 tarihleri arasında toplam 309 adet C. kosswigi ve 288 adet B. ercisianus elektrikle avclık yolu ile yakalanmıştı. C.atal boylar $C$. kosswigi'de $3,7-26,1 \mathrm{~cm}$, B. ercisianus'ta 4,3-22,7 cm; ağırlık ise $C$. kosswigi'de 0,6-227,4 ve $B$. ercisianus'ta $1,2-140,0 \mathrm{~g}$ arasında belirlenmiştir. En yoğun avcllık C. kosswigi populasyonunda $5.0-6,9(\% 27,5) \mathrm{cm}$ ve $0-19,9(\% 67,0)$ g'llk gruplarda, B. ercisianus'ta ise $12,0-13,9(\% 24,7) \mathrm{cm}$ ve $0-9,9(\% 23,3)$ g'lık gruplarda gerçekleşmiştir. Kondisyon faktörü C. kosswigi'de $1,305 \pm 0,008(0,798-1,886)$, B. ercisianus'ta $1,158 \pm 0,006(0,864-1,559)$ olarak belirlenmistir. Boy-ağırlık iliskisi $C$. kosswigide $W=0,01435 \times L^{2,952}\left(r^{2}=0,996\right)$. B. ercisianus'ta ise $W=0,01276 \times L^{2,959}$ $\left(r^{2}=0,994\right)$ olarak hesaplanmıştı. Erkek:dişi oranı $C$. kosswigi'de 1:0,15 ile B. ercisianus'ta 1:0,64 olarak hesaplanmıştır. C. kosswiginnin cinsel olgunluğa erkeklerde $11 \mathrm{~cm}$, dişilerde ise $18 \mathrm{~cm}$ çatal boyda ulaştı̆ı tespit edilmiştir. B. ercisianus'ta cinsel olgunluk boyu erkeklerde $9 \mathrm{~cm}$, dişilerde ise $12 \mathrm{~cm}$ çatal boyda gerçekleşmiştir. C. kosswigi'de üremenin Mayıs ayının 1. haftası ile Temmuz ayının 2. haftası arasında, B. ercisianus'ta ise Mayıs ayının 1. haftası ile Ağustos ayının ilk haftası arasında gerçekleştiği belirlenmiş̧ir. Türlerin devamllığı için avlanma boyunun $C$. kosswigi için $20 \mathrm{~cm}$ çatal boy, B. ercisianus için ise $15 \mathrm{~cm}$ çatal boy altında olmaması gerekmektedir.

Anahtar kelimeler: Barbus ercisianus, Capoeta kosswigi, büyüme, boy-ağırlık ilişkisi, üreme

\section{INTRODUCTION}

Determination of the population dynamics parameters such as reproduction, growth, mortality, and length weight relationships (LWRs) in monitoring natural fish populations and using them efficiently and sustainably is the main subject of fisheries biology (Haimovici and Velasco, 2000).

LWRs provide a quick effective method for assessing the weight of a particular fish species by estimating the weight from length observations obtained on the field and the equations can be used to estimate fish stock biomass from limited data (Kimmerer et al., 2005; Froese et al., 2011). LWRs can be used to measure changes in the health of a fish population, determine the relative condition of small fish compared to large fish and compare the condition of a fish population (Froose, 2006). Fish can show either isometric or allometric growth (Sakar et al., 2013). Isometric growth $(b=3)$ indicates that both length and weight of the fish are increasing at the same rate. Allometric growth can be either positive or negative. Positive allometric $(b>3)$ implies that the fish becomes stouter, or heavier or deeper-bodied as its length increases. Negative allometric $(b<3)$ implies the fish becomes slender or lighter as its length increases (Wootton, 1998).

Fulton's Condition factor $(\mathrm{K})$ is an estimation of general well being of fish and a useful index for estimating growth rate and age and for assessing environmental quality (Ricker, 
1975). The Fulton condition factor of 1.0 or greater shows the good condition of fish while less than 1.0 indicates poor condition (Abobi, 2015). The condition factor may differ due to one or more factors such as season, sex, type of food organism consumed by fish, age of fish, amount of fat reserved and environmental conditions (Bagenal and Tesch, 1978; Sakar et al., 2013).

Reproduction is an important physiological system that is crucial in the life cycle of fish and has many characters unique to aquatic life (Bagenal and Tesch, 1978). The reproductive success of a species is determined by its genetic capacities depending on ecological conditions. Reproduction is of vital importance in fish, as in other living things, to ensure the continuity of species. Although a fish can grow and develop in a water source or its environment, it is not considered to have adapted to that environment if it does not have reproductive characteristics. Therefore, it is necessary to determine the growth and reproductive biology of the species to develop successful fisheries management. The gonadosomatic index (GSI), is described as gonad mass as a percentage of total body weight. This index is widely used as a simple measure of the extent of reproductive investment, gonadal development and maturity of fish in relation to spawning. GSI of fish increases with maturity and abruptly declines after spawning. Thus, GSI is particularly helpful in identifying season of spawning (Wootton, 1992; Çetinkaya et al., 2005; Karataş et al., 2005).

Capoeta and Barbus genera (Familia: Cyprinidae) shows a widespread distribution in Asia and the Middle East, while the Barbus genus shows a distribution in Europe. The different species live in many water sources (Geldiay and Balık, 2009; Türkmen et al., 2002).

Located at the east of Turkey, which features a closed basin, the Lake Van Basin is very rich in terms of diversity of fish species. Five of 9 fish species in the basin are endemic (Şen et al., 2018). C. kosswigi and B. ercisianus are among the endemic fish of the basin (Elp et al., 2016; Elp, 2017).

C. kosswigi and $B$. ercisianus are firstly recorded by Karaman et al, (1969) and (1971) in Erciş, Karasu and Hoşap streams which are flow into the Lake Van. While $C$. kosswigi has a couple of short barbels, $B$. ercisianus has two pairs of barbels. The body of both species are long and covered with a large number of small scales, and reproductive tubercles are observed on the body, especially in the head, during the reproductive period. They prefer sandy and pebbly bottoms and with flowing, clean, cold and high oxygen content water (Geldiay and Balık, 2009).

This study was carried out for the purpose of determination of growth and reproduction properties and evaluate the current situation of $C$. kosswigi and $B$. ercisianus populations in Deliçay Stream.

\section{MATERIAL AND METHODS}

\section{Study area}

The present study was carried out in Deliçay Stream, which flows into the Lake Van. Deliçay Stream is formed by the rain and small waters coming from the Morgedik Dam and the hills around it and the melted snow waters. It has approximately $45-50 \mathrm{~km}$ length and an average annual flow rate of $2.8 \mathrm{~m}^{3}$ (Çetinkaya, 1993). There is also a regulator on the river (Figure 1).

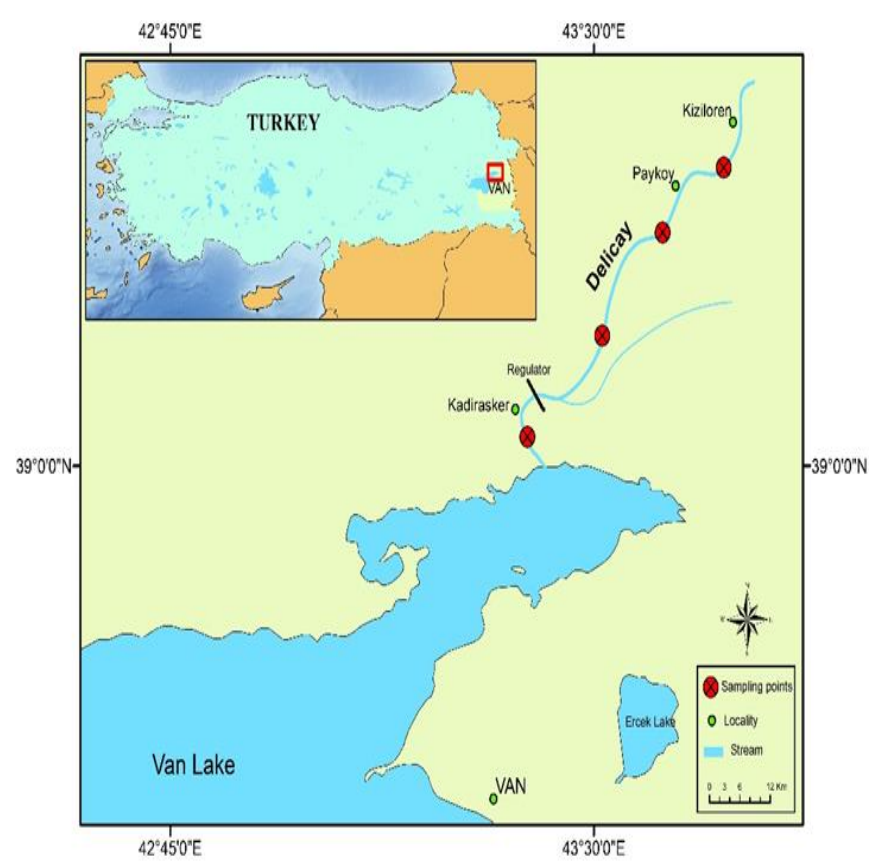

Figure 1. Sampling sites at Deliçay Stream

\section{Fish collection}

An electrofishing method (SAMUS 725 MS) was used to catch fish samples with the permission of the Van Yüzüncü YIl University (Turkey) Animal Researches Local Ethic Committee. During the study, a total of 309 C. kosswigi and 288 B. ercisianus were monthly collected from April 2018 to August 2018 at four stations: Kadirasker, Deliçay, Payköy and KızIören (Figure 1).

\section{Laboratory procedures}

Fish samples were measured to the nearest $0.1 \mathrm{~cm}$ for fork length (FL) and to the nearest $0.1 \mathrm{~g}$ for total weight (W). Total length-weight relationships were determined using the equation: $W=a \times L^{b}$, where $W$ is weight $(W), L$ is length $(L), a$ is the intercept, and $b$ is the slope (Le Cren, 1951). Fulton's Condition Factor was calculated using $K=\left(W / L^{3}\right) \times 100$, where $W=$ weight of fish $(\mathrm{g}), \mathrm{L}=$ total length of fish $(\mathrm{cm})$ (Ricker, 1975).

The gonads were removed and observed morphologically. Sex was recorded for each fish. The sex of the fish was categorized as male, female, or juvenile. The first 
reproduction length and weight of the fish were determined according to the maturity status of the gonads (Crim and Glebe, 1990). Gonadosomatic Index value was calculated using the formula $\mathrm{GSI}=(\mathrm{Gw} / \mathrm{W}) \times 100$, where $\mathrm{Gw}=$ gonad weight of fish $(\mathrm{g}), \mathrm{W}=$ total weight of fish $(\mathrm{g})$ (Karataş et al., 2005).

\section{Statistical analysis}

The growth types for the specimens were determined using the Student t-test. The t-test statistics values were calculated and compared with critical values from the T-Table to check if the growth type is isometric $(b=3)$ or allometric ( $b$ $\neq 3$ ) (Pajuelo and Lorenzo, 1998). The sex ratio was tested by the chi-square test $\left(X^{2}\right)$ to indicate whether there was a deviation from a 1:1 ratio (Zar, 1999). The means, variance, standard error, regression, correlation values, and the comparisons of population parameters obtained from the study were performed with SPSS 21.0 and Microsoft Excel 2016.

\section{RESULTS}

\section{Growth in length}

Fork length values of $309 \mathrm{C}$. kosswigi specimens in the population were ranged from 3.7 to $26.1 \mathrm{~cm}(\mathrm{n}=309)$ for all population, 4.8 to $21.8 \mathrm{~cm}(\mathrm{n}=113)$ for males, 18.0 to 26.1 $\mathrm{cm}(\mathrm{n}=17)$ for females, and 3.7 to $11.4 \mathrm{~cm}(\mathrm{n}=179)$ for juveniles. The lengths were grouped into $2 \mathrm{~cm}$ and the length frequency distributions were examined. It was determined that the most dominant groups were found as $5.0-6.9 \mathrm{~cm}(27.5 \%)$ for all samples, $13.0-14.9 \mathrm{~cm}(9.7 \%)$ for males, $19.0-20.9 \mathrm{~cm}$ (1.9\%) for females, and $5.0-6.9 \mathrm{~cm}(26.9 \%)$ for juveniles (Table 1).

Table 1. Length groups of Capoeta kosswigi in the Deliçay Stream

\begin{tabular}{|c|c|c|c|c|c|c|c|c|}
\hline \multirow{2}{*}{$\begin{array}{l}\text { Fork length } \\
\text { groups } \\
(\mathrm{cm})\end{array}$} & \multicolumn{2}{|c|}{ Male } & \multicolumn{2}{|c|}{ Famale } & \multicolumn{2}{|c|}{ Juvenil } & \multicolumn{2}{|c|}{ Total } \\
\hline & $n$ & $\%$ n & $n$ & $\%$ n & $\mathrm{n}$ & $\% n$ & $n$ & $\% n$ \\
\hline $3.0-4.9$ & 2 & 0.6 & 0 & 0.0 & 64 & 20.7 & 67 & 21.7 \\
\hline $5.0-6.9$ & 2 & 0.6 & 0 & 0.0 & 83 & 26.9 & 85 & 27.5 \\
\hline $7.0-8.9$ & 7 & 2.3 & 0 & 0.0 & 27 & 8.7 & 34 & 11.0 \\
\hline $9.0-10.9$ & 9 & 2.9 & 0 & 0.0 & 4 & 1.3 & 13 & 4.2 \\
\hline $11.0-12.9$ & 17 & 5.5 & 0 & 0.0 & 1 & 0.3 & 18 & 5.8 \\
\hline $13.0-14.9$ & 30 & 9.7 & 0 & 0.0 & 0 & 0.0 & 30 & 9.7 \\
\hline $15.0-16.9$ & 23 & 7.4 & 0 & 0.0 & 0 & 0.0 & 23 & 7.4 \\
\hline $17.0-18.9$ & 15 & 4.9 & 2 & 0.6 & 0 & 0.0 & 17 & 5.5 \\
\hline $19.0-20.9$ & 6 & 1.9 & 6 & 1.9 & 0 & 0.0 & 12 & 3.9 \\
\hline $21.0-22.9$ & 2 & 0.6 & 5 & 1.6 & 0 & 0.0 & 7 & 2.3 \\
\hline $23.0 \leq$ & 0 & 0.0 & 4 & 1.3 & 0 & 0.0 & 4 & 1.3 \\
\hline Total & 113 & 36.6 & 17 & 5.5 & 179 & 57.9 & 309 & 100.0 \\
\hline
\end{tabular}

The fork lengths for $B$. ercisianus were varied from 4.3$22.7 \mathrm{~cm}(\mathrm{n}=288)$ for all samples, 8.0-15.9 $\mathrm{cm}(\mathrm{n}=145)$ for males, $12.4-22.7 \mathrm{~cm}(\mathrm{n}=92)$ for females and 4.3-7.8 cm $(\mathrm{n}=$ 51) for juveniles. According to $2 \mathrm{~cm}$ length groups, it was observed that the largest length groups were found as 12.0$13.9 \mathrm{~cm}$-group (24.7\%) for all samples, $12.0-13.9 \mathrm{~cm}$-group (23.0\%) for males, $16.0-17.9 \mathrm{~cm}$-group $(12.5 \%)$ for females, and 6.0-7.9 cm-group (9.4\%) for juveniles (Table 2 ).

Table 2. Length groups of Barbus ercisianus in the Deliçay Stream

\begin{tabular}{|c|c|c|c|c|c|c|c|c|}
\hline \multirow{2}{*}{$\begin{array}{l}\text { Fork length } \\
\text { groups } \\
(\mathrm{cm})\end{array}$} & \multicolumn{2}{|c|}{ Male } & \multicolumn{2}{|c|}{ Famale } & \multicolumn{2}{|c|}{ Juvenil } & \multicolumn{2}{|c|}{ Total } \\
\hline & $\mathbf{n}$ & $\% n$ & $\mathrm{n}$ & $\%$ n & $\mathrm{n}$ & $\% n$ & $\mathrm{n}$ & $\% n$ \\
\hline $4.0-5.9$ & 0 & 0.0 & 0 & 0.0 & 24 & 8.3 & 24 & 8.3 \\
\hline $6.0-7.9$ & 0 & 0.0 & 0 & 0.0 & 27 & 9.4 & 27 & 9.4 \\
\hline $8.0-9.9$ & 23 & 8.0 & 0 & 0.0 & 0 & 0.0 & 23 & 8.0 \\
\hline $10.0-11.9$ & 40 & 13.9 & 0 & 0.0 & 0 & 0.0 & 40 & 13.9 \\
\hline $12.0-13.9$ & 66 & 23.0 & 5 & 1.7 & 0 & 0.0 & 71 & 24.7 \\
\hline $14.0-15.9$ & 16 & 5.5 & 8 & 2.8 & 0 & 0.0 & 24 & 8.3 \\
\hline $16.0-17.9$ & 0 & 0.0 & 36 & 12.5 & 0 & 0.0 & 36 & 12.5 \\
\hline $18.0-19.9$ & 0 & 0.0 & 34 & 11.8 & 0 & 0.0 & 34 & 11.8 \\
\hline $20.0 \leq$ & 0 & 0.0 & 9 & 3.1 & 0 & 0.0 & 9 & 3.1 \\
\hline Total & 145 & 50.3 & 92 & 31.9 & 51 & 17.7 & 288 & 100.0 \\
\hline
\end{tabular}




\section{Growth in weight}

The ranges of total weight in $C$. kosswigi population were found between 0.6-227.4 $\mathrm{g}(\mathrm{n}=309)$ for all the samples, 1.2$134.2 \mathrm{~g}(\mathrm{n}=113)$ for males, $78.5-227.4 \mathrm{~g}(\mathrm{n}=17)$ for females, and 0.6-17.6 $\mathrm{g}(\mathrm{n}=179)$ for juveniles.

The weights were grouped into $20 \mathrm{~g}$ sample groups and the weight-frequencies were investigated. It was determined that the dominant weight groups were found as $0.0-19.9 \mathrm{~g}$ $(67.0 \%)$ for all samples, $20.0-39.9 \mathrm{~g}(10.4 \%)$ for males, 100.0 -
$119.9 \mathrm{~g}(1.9 \%)$ for females, and $0.0-19.9 \mathrm{~g}(57.9 \%)$ for juveniles (Table 3 ).

The total weight values of $B$. ercisianus were ranged from 1.2 to $140.0 \mathrm{~g}(\mathrm{n}=288)$ for all samples, 5.6 to $44.6 \mathrm{~g}(\mathrm{n}=$ 145) for males, 23.9 to $140.0 \mathrm{~g}(\mathrm{n}=92)$ for females, and 1.2 to $5.6 \mathrm{~g}(\mathrm{n}=51)$ for juveniles. According to $10 \mathrm{~g}$ weight groups, it was determined that the largest weight groups were found as 0-9.9 $\mathrm{g}(23.3 \%)$ for all samples, $20.0-29.9 \mathrm{~g}(19.8 \%)$ for males, $70.0-79.9 \mathrm{~g}(6.6 \%)$ for females, and $0-9.9 \mathrm{~g}$ (17.7\%) for juveniles (Table 4).

Table 3. Weight groups of Capoeta kosswigi in the Deliçay Stream

\begin{tabular}{|c|c|c|c|c|c|c|c|c|}
\hline \multirow{2}{*}{$\begin{array}{l}\text { Weight } \\
\text { groups (g) }\end{array}$} & \multicolumn{2}{|c|}{ Male } & \multicolumn{2}{|c|}{ Famale } & \multicolumn{2}{|c|}{ Juvenile } & \multicolumn{2}{|c|}{ Total } \\
\hline & $\mathrm{n}$ & $\% n$ & $n$ & $\% n$ & $\mathrm{n}$ & $\% n$ & $\mathrm{n}$ & $\% n$ \\
\hline $0-19.9$ & 28 & 9.1 & 0 & 0.0 & 179 & 57.9 & 207 & 67.0 \\
\hline $20.0-39.9$ & 32 & 10.4 & 0 & 0.0 & 0 & 0.00 & 32 & 10.4 \\
\hline $40.0-59.9$ & 28 & 9.1 & 0 & 0.0 & 0 & 0.00 & 28 & 9.1 \\
\hline $60.0-79.9$ & 17 & 5.5 & 2 & 0.6 & 0 & 0.00 & 19 & 6.1 \\
\hline $80.0-99.9$ & 4 & 1.3 & 1 & 0.3 & 0 & 0.00 & 5 & 1.6 \\
\hline $100.0-119.9$ & 3 & 1.0 & 6 & 1.9 & 0 & 0.00 & 9 & 2.9 \\
\hline $120.0-139.9$ & 1 & 0.3 & 3 & 1.0 & 0 & 0.00 & 4 & 1.3 \\
\hline $140.0 \leq$ & 0 & 0.0 & 5 & 1.6 & 0 & 0.00 & 5 & 1.6 \\
\hline Total & 113 & 36.6 & 17 & 5.5 & 179 & 57.9 & 309 & 100.0 \\
\hline
\end{tabular}

Table 4. Weight groups of Barbus ercisianus in the Deliçay Stream

\begin{tabular}{|c|c|c|c|c|c|c|c|c|}
\hline \multirow{2}{*}{$\begin{array}{l}\text { Weight } \\
\text { groups (g) }\end{array}$} & \multicolumn{2}{|c|}{ Male } & \multicolumn{2}{|c|}{ Famale } & \multicolumn{2}{|c|}{ Juvenile } & \multicolumn{2}{|c|}{ Total } \\
\hline & $n$ & $\% n$ & $\mathrm{n}$ & $\% n$ & $\mathrm{n}$ & $\% n$ & $n$ & $\% n$ \\
\hline $0-9.9$ & 16 & 5.6 & 0 & 0.0 & 51 & 17.7 & 67 & 23.3 \\
\hline $10.0-19.9$ & 52 & 18.1 & 0 & 0.0 & 0 & 0.0 & 52 & 18.1 \\
\hline $20.0-29.9$ & 57 & 19.8 & 5 & 1.7 & 0 & 0.0 & 62 & 21.5 \\
\hline $30.0-39.9$ & 15 & 5.2 & 4 & 1.4 & 0 & 0.0 & 19 & 6.6 \\
\hline $40.0-49.9$ & 5 & 1.7 & 9 & 3.1 & 0 & 0.0 & 14 & 4.9 \\
\hline $50.0-59.9$ & 0 & 0.0 & 18 & 6.3 & 0 & 0.0 & 18 & 6.3 \\
\hline $60.0-69.9$ & 0 & 0.0 & 18 & 6.3 & 0 & 0.0 & 18 & 6.3 \\
\hline $70.0-79.9$ & 0 & 0.0 & 19 & 6.6 & 0 & 0.0 & 19 & 6.6 \\
\hline $80.0-89.9$ & 0 & 0.0 & 9 & 3.1 & 0 & 0.0 & 9 & 3.1 \\
\hline $90.0-99.9$ & 0 & 0.0 & 5 & 1.7 & 0 & 0.0 & 5 & 1.7 \\
\hline $100 \leq$ & 0 & 0.0 & 5 & 1.7 & 0 & 0.0 & 5 & 1.7 \\
\hline Total & 145 & 50.3 & 92 & 31.9 & 51 & 17.7 & 288 & 100.0 \\
\hline
\end{tabular}

\section{Length-weight relationships}

Length-weight relationships for both species are shown in Table 5. Strong relationships were found between length and weight for these species in the study $\left(r^{2}=0.948\right.$ to 0.996$)$.

The length-weight relationships of $C$. kosswigi were calculated as $W=0.01435 \times L^{2.952}\left(r^{2}=0.996\right)$ for all samples, $W=0.01854 \times L^{2.858}\left(r^{2}=0.987\right)$ for males, $W=0.02079 \times$ $L^{2.843}\left(r^{2}=0.952\right)$ for females, and $W=0.01574 \times L^{2.895}\left(r^{2}=\right.$ 0.980 ) for juvenile. The isometric growth pattern was observed for all the samples, females and juveniles ( $p>0.05$ ), whereas the growth pattern for males was negative allometric $(p<0.05)$ (Table 5).

The length-weight relationship equations for $B$. ercisianus were calculated as $W=0.01276 \times L^{2.959}\left(r^{2}=0.994\right)$ for all samples, $W=0.01476 \times L^{2.901}\left(r^{2}=0.962\right)$ for males, $W=$ $0.01949 \times L^{2.813}\left(r^{2}=0.948\right)$ for females, and $W=0.01343 \times$ $L^{2.927}\left(r^{2}=0.960\right)$ for juveniles. It was determined that the growth pattern for $B$. ercisianus for all groups was found as isometric $(p>0.05)$ (Table 5). 
Table 5. The descriptive statistics and estimated parameters of length-weight relationships of $C$. kosswigi and $B$. ercisianus populations in the Deliçay Stream

\begin{tabular}{|c|c|c|c|c|c|c|c|c|c|}
\hline \multirow{2}{*}{ Species } & \multirow{2}{*}{ Sex } & \multirow{2}{*}{$\mathrm{n}$} & \multicolumn{4}{|c|}{ Regression parameters } & \multirow{2}{*}{$\begin{array}{c}\text { Student's } \\
\text { t-test }\end{array}$} & \multirow{2}{*}{$p$} & \multirow[t]{2}{*}{ Growth type } \\
\hline & & & $a$ & b & $\mathrm{SE}_{\mathrm{b}}$ & $\mathrm{r}^{2}$ & & & \\
\hline \multirow{4}{*}{ C. kosswigi } & Male & 113 & 0.01854 & 2.858 & 0.031 & 0.987 & -2.190 & $0.044^{*}$ & $A(-)$ \\
\hline & Female & 17 & 0.02079 & 2.843 & 0.166 & 0.952 & -0.422 & 0.746 & I \\
\hline & Juvenil & 179 & 0.01574 & 2.895 & 0.031 & 0.980 & -0.493 & 0.656 & I \\
\hline & Total & 309 & 0.01435 & 2.952 & 0.011 & 0.996 & -0.380 & 0.723 & I \\
\hline \multirow{4}{*}{ B. ercisianus } & Male & 145 & 0.01476 & 2.901 & 0.048 & 0.962 & -0.762 & 0.489 & I \\
\hline & Female & 92 & 0.01949 & 2.813 & 0.069 & 0.948 & -1.905 & 0.129 & I \\
\hline & Juvenil & 51 & 0.01343 & 2.927 & 0.085 & 0.960 & -0.771 & 0.521 & I \\
\hline & Total & 288 & 0.01276 & 2.959 & 0.013 & 0.994 & -1.958 & 0.122 & I \\
\hline
\end{tabular}

$\mathrm{n}=$ number of individuals, $\mathrm{a}=$ proportionality constant, $\mathrm{b}=$ slope of the relationship; $\mathrm{SE}_{\mathrm{b}}$, standard error of $\mathrm{b} ; \mathrm{r}^{2}=$ coefficient of determination; $\mathrm{I}=$ isometric growth; $A=$ allometric growth.

${ }^{*}$ Statistically different $(p<0.05)$.

\section{Fulton's condition factor}

Fulton's condition factor, $\mathrm{K}$, was used to assess the degree of well-being of $C$. kosswigi and $B$. ercisianus in the Deliçay Stream which provides information on the environmental quality and suitability.

Fulton's condition factor of $C$. kosswigi was calculated as $1.305 \pm 0.008(0.798-1.886)$ for all samples, $1.287 \pm 0.013$ $(0.798-1.870)$ for males, $1.288 \pm 0.022(1.154-1.470)$ for females, and $1.319 \pm 0.010(0.911-1.886)$ for juveniles. The mean lowest condition value was determined in August $(1.272 \pm 0.012)$, whereas the highest in May $(1.364 \pm 0.074)$ (Figure 2).

Fulton's condition factor for $B$. ercisianus was determined as $1.158 \pm 0.006(0.864-1.559)$ for overall, $1.159 \pm 0.008$ (0.884-1.491) for males, $1.143 \pm 0.010(0.890-1.559)$ for females, and $1.180 \pm 0.016(0.864-1.509)$ for juveniles. The mean condition factor ranged from $1.125 \pm 0.010$ in July to $1.236 \pm 0.042$ in May (Figure 2).

\section{Reproduction}

In the population of C. kosswigi, $113(86.9 \%)$ of the specimens collected were male and $17(13.1 \%)$ were female.
Male:female ratio was calculated as 1:0.15. The chi-square analysis showed that the sex ratio was significantly different from the expected ratio ( $X^{2}$ test, $\left.p<0.05\right)$ (Table 6).

Sex was determined on 237 specimens for $B$. ercisianus. $145(61.2 \%)$ samples were male and $92(38.8 \%)$ samples were female. The M:F ratio was determined as 1:0.64. The sex ratio was found to be significantly different from equality 1:1 ( $X^{2}$ test, $\left.p<0.05\right)$ (Table 6).

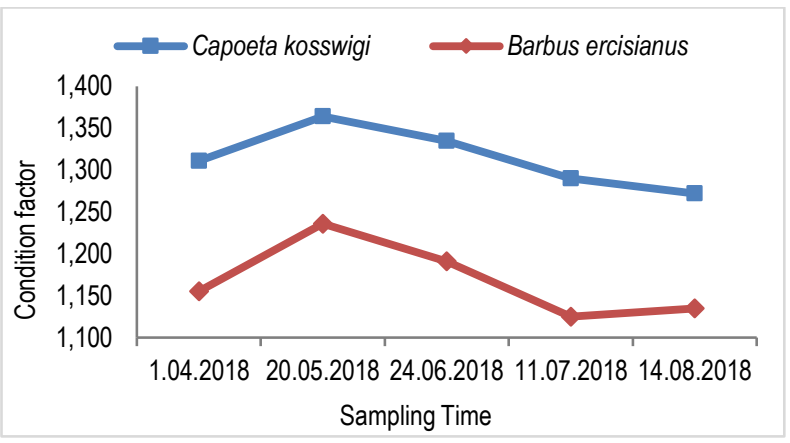

Figure 2. Fulton's condition factor changes for Capoeta kosswigi and Barbus ercisianus in the Deliçay Stream

Table 6. M:F ratio of the Capoeta kosswigi and Barbus ercisianus populations in the Deliçay Stream

\begin{tabular}{|c|c|c|c|c|c|c|c|c|}
\hline \multirow[t]{2}{*}{ Species } & \multicolumn{2}{|c|}{ Male } & \multicolumn{2}{|c|}{ Female } & \multirow[t]{2}{*}{$M+F$} & \multirow{2}{*}{$M: F$} & \multirow[t]{2}{*}{$x^{2}$} & \multirow[t]{2}{*}{ Result } \\
\hline & $\mathrm{n}$ & $\% n$ & $\mathbf{n}$ & $\% \mathrm{n}$ & & & & \\
\hline C. kosswigi & 113 & 86.9 & 17 & 13.1 & 130 & $1: 0.15$ & 70.89 & $p<0.05$ \\
\hline B. ercisianus & 145 & 61.2 & 92 & 38.8 & 237 & $1: 0.64$ & 12.30 & $p<0.05$ \\
\hline
\end{tabular}

The sexual maturity for $C$. kosswigi was determined on 130 samples. Total 116 of the overall samples was mature and 14 was immature. Of the 113 males, 99 were identified as mature, while all the females were found as mature. When the sexual maturation was examined according to $1 \mathrm{~cm}$ length groups, it was determined that maturation occurred at $11 \mathrm{~cm}$ $(100 \%) \mathrm{FL}$ for males and $18 \mathrm{~cm}(100.0 \%) \mathrm{FL}$ for females (Table 7).
The sexual maturity for $B$. ercisianus was determined on 237 samples. Total 216 of the overall samples was mature and 21 was immature. Of the 145 males, 124 were identified as mature, while all the females were found as mature.

According to $1 \mathrm{~cm}$ length groups, males matured at $9 \mathrm{~cm}$ (85.7\%) fork length and females at $12 \mathrm{~cm} \mathrm{(100.0 \% )} \mathrm{fork}$ length (Table 8). 
Table 7. Sexual maturity groups of Capoeta kosswigi in the Deliçay Stream

\begin{tabular}{lllll}
\hline $\begin{array}{l}\text { Fork length } \\
\text { groups } \\
(\mathrm{cm})\end{array}$ & Male & $\begin{array}{l}\text { Mature }(-) \\
\mathbf{n}(\% \mathrm{n})\end{array}$ & $\begin{array}{l}\text { Female } \\
\text { Mature }(+) \\
\mathbf{n}(\% \mathbf{n})\end{array}$ & $\begin{array}{l}\text { Mature }(-) \\
\mathbf{n}(\%)\end{array}$ \\
$\leq 10$ & $(\% \mathrm{n})$ & $14(70.0)$ & 0 & 0 \\
11 & $6(30.0)$ & 0 & 0 & 0 \\
12 & $11(100.0)$ & 0 & 0 & 0 \\
13 & $6(100.0)$ & 0 & 0 & 0 \\
14 & $9(100.0)$ & 0 & 0 & 0 \\
15 & $21(100.0)$ & 0 & 0 & 0 \\
16 & $15(100.0)$ & 0 & 0 & 0 \\
17 & $8(100.0)$ & 0 & 0 & 0 \\
18 & $7(100.0)$ & 0 & $2(100.0)$ & 0 \\
19 & $8(100.0)$ & 0 & $2(100.0)$ & 0 \\
20 & $4(100.0)$ & 0 & $4(100.0)$ & 0 \\
21 & $2(100.0)$ & 0 & $2(100.0)$ & 0 \\
$22 \leq$ & $2(100.0)$ & 0 & $7(100.0)$ & 0 \\
Total & 0 & 14 & 17 & 0 \\
\hline
\end{tabular}

Table 8. Sexual maturity groups of Barbus ercisianus in the Deliçay Stream

\begin{tabular}{|c|c|c|c|c|}
\hline \multirow{2}{*}{$\begin{array}{l}\text { Fork length } \\
\text { groups } \\
\text { (cm) }\end{array}$} & \multicolumn{2}{|l|}{ Male } & \multicolumn{2}{|l|}{ Female } \\
\hline & $\begin{array}{l}\text { Mature (+) } \\
(\% \mathrm{n})\end{array}$ & $\begin{array}{l}\text { Mature (-) } \\
\mathrm{n}(\% \mathrm{n})\end{array}$ & $\begin{array}{l}\text { Mature (+) } \\
\mathrm{n}(\% \mathrm{n})\end{array}$ & $\begin{array}{l}\text { Mature (-) } \\
\mathrm{n}(\% \mathrm{n})\end{array}$ \\
\hline$\leq 8.9$ & $3(33.3)$ & $6(66.7)$ & 0 & 0 \\
\hline 9 & $12(85.7)$ & $2(14.3)$ & 0 & 0 \\
\hline 10 & $13(86.7)$ & $2(13.3)$ & 0 & 0 \\
\hline 11 & $21(84.0)$ & $4(16.0)$ & 0 & 0 \\
\hline 12 & 37 (84.1) & $7(15.9)$ & $2(100.0)$ & 0 \\
\hline 13 & $22(100.0)$ & 0 & $3(100.0)$ & 0 \\
\hline 14 & $10(100.0)$ & 0 & $4(100.0)$ & 0 \\
\hline 15 & $6(100.0)$ & 0 & $4(100.0)$ & 0 \\
\hline 16 & 0 & 0 & $14(100.0)$ & 0 \\
\hline 17 & 0 & 0 & $22(100.0)$ & 0 \\
\hline 18 & 0 & 0 & $19(100.0)$ & 0 \\
\hline 19 & 0 & 0 & $15(100.0)$ & 0 \\
\hline 20 & 0 & 0 & $5(100.0)$ & 0 \\
\hline 21 & 0 & 0 & $3(100.0)$ & 0 \\
\hline $22 \leq$ & 0 & 0 & $1(100.0)$ & 0 \\
\hline Total & 124 & 21 & 92 & 0 \\
\hline
\end{tabular}

The GSI values were calculated to determine the reproduction for both populations. The total GSI for $C$. kosswigi was calculated between 0.389 and 16.000 with an average of $2.392 \pm 0.243$. This value was determined as $2.059 \pm 0.252(0.389-16.000)$ for males and $3.880 \pm 0.605$ (1.259-9.776) for females. The mean GSI for all samples peaked in May $(5.621 \pm 2.930)$, whereas the lowest in July
(1.227 \pm 0.162 ) (Figure 3). The total GSI value for $B$. ercisianus ranged from 0.282 to 16.924 with an average of $4.184 \pm 0.212$. This value was calculated as $4.032 \pm 0.265$ (0.282-15.441) for males and 4.388 $\pm 0.346(0.540-16.924)$ for females. The highest GSI for all samples was in May $(6.877 \pm 1.084)$, while the lowest in August $(1.429 \pm 0.091)$ (Figure 3). 


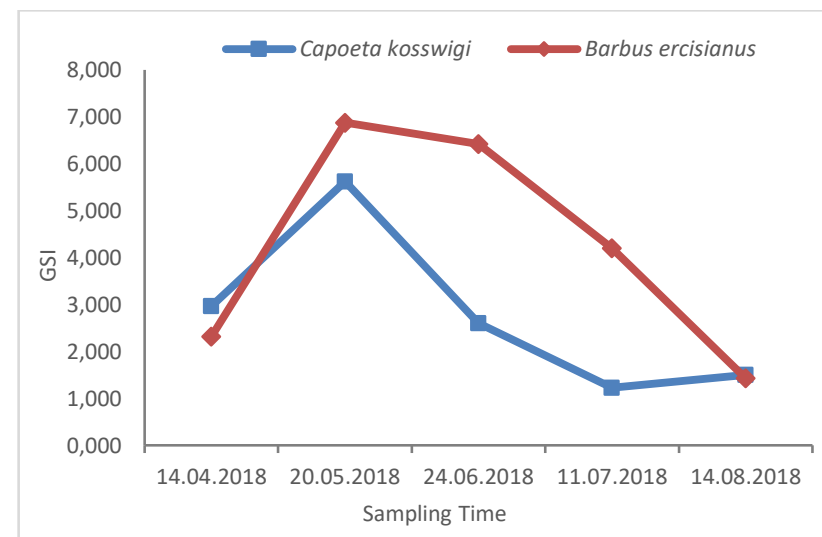

Figure 3. GSI changes for Capoeta kosswigi and Barbus ercisianus in the Deliçay Stream

\section{DISCUSSION}

In this study, the sample size ranged from 309 specimens for $C$. kosswigi to 288 specimens for $B$. ercisianus. The lenght and weight ranges for males was lower than for females in both species.

The maximum length and weight values for $C$. kosswigi were smaller than the previous studies in Lake Van Basin (Table 9). The $b$ value is considered as an indicator showing the nutritional status and growth of the fish. It is affected by the water temperature, the abundance of nutrients in the environment, and other properties. In practice, values of $b$ smaller, equal and larger than 3 indicate isometry, negative allometry and positive allometry respectively (Wootton, 1998). The growth types of $C$. kosswigi for all the samples, females, and juveniles were isometric growth $(p>0.05)$, while the growth type for males was negative allometric growth $(p<0.05)$. On the other hand, the b values for $C$. kosswigi in our study were within the values (2.5-3.5) reported by Froese (2006). Population characteristics of C. kosswigi presented different studies are given in Table 9 .

Fulton's condition factor value is related to the body shape of the fish. It is used as an indicator of long-term changing nutritional balance in comparison of fish populations of the same species living under similar or different conditions such as condition factor, nutrient density, climatic conditions, determination of gonad maturity time and duration and nutritional activity (Bogler and Connolly, 1989; Yılmaz et al., 2003; Çetinkaya et al., 2005). Wootton (1992) reported that fish with higher $\mathrm{K}$ values $(>1)$ are in a better condition than fish with lower $K$ values $(<1)$. In this study, $K$ values ranged from 0.798 to 1.886 with a mean value of 1.305 (Table 9) which indicates that fish were in good condition during the study period in the aquatic ecosystem. Fulton's condition factor values of the Capoeta species are shown in Table 9. In the previous studies conducted in our study, the condition factor ranged between 1.234 (Nazik Lake) and 1.452 (Karasu River).

The sex ratio was close to $1: 1$ in many species, and it sometimes can vary from species to species, even from different sources of the same species in different years or different populations (Nikolsky, 1963). In the present study, the overall $M: F$ ratio of the population was $1: 0.15$, for all of the investigated samples in $C$. kosswigi. The chi-square analysis showed that the sex ratio was significantly different from the expected $1: 1$ ratio $\left(x^{2}=70.89, p<0.05\right)$. In this study, the males were found to be dominant. Due to the large size of females, prey pressure is thought to be more intense on females. It was reported in Table 9 that the males were dominant in Nazik Lake (1:0.77), Karasu River (1:0.85) and Çığlı Stream (1:0.77), whereas females were dominant in Koçköprü (1:1.43) and Zernek Dam Lakes (1:1.72).

Sexual maturation for C. kosswigi was occured at $11 \mathrm{~cm}$ FL for males and $18 \mathrm{~cm}$ FL for females in this study. In Lake Van Basin, females reach sexual maturity for $C$. kosswigi at a larger size than males. These sexual maturity sizes were observed at $15 \mathrm{~cm}$ for males and $22 \mathrm{~cm}$ for females from Nazik Lake (Şen et al., 1999), $23 \mathrm{~cm}$ for males and $33 \mathrm{~cm}$ for females from Koçköprü Dam Lake (Elp and Karabatak, 2007), $14 \mathrm{~cm}$ for males and $22 \mathrm{~cm}$ for females from Zernek Dam Lake (Şen et al., 2008), $11 \mathrm{~cm}$ for males and $23 \mathrm{~cm}$ for females from Karasu River (Elp and Şen, 2009), $10 \mathrm{~cm}$ for males and $18 \mathrm{~cm}$ for females from Çığlı Stream (Şen et al., 2014). In addition, it was determined that the C. kosswigi population in Deliçay Stream had reached sexual maturity size before the population of $C$. kosswigi from Nazik Lake, Zernek Dam Lake and Koçköprü Dam Lake. The water temperature and nutrition may be effective in this result.

Reproduction in fish is a very complex vital activity, and reproduction has vital importance to ensure species survival in fish as in other living things. (Karataş et al., 2005). The mean GSI value for C. kosswigi piked in May (5.621 \pm 2.930$)$ and then declined. The lowest GSI value was determined in July $(1.227 \pm 0.162)$. Spawning season of $C$. kosswigi took place intensively from $1^{\text {st }}$ week of May to $2^{\text {nd }}$ week of July in Deliçay Stream. Spawning season of C. kosswigi was reported in Lake Van Basin between May and July from Nazik Lake (Şen et al., 1999), May and June from Koçköprü Dam Lake (Elp and Karabatak, 2007), June and July from Zernek Dam Lake (Şen et al., 2008) and May and July from Çığlı Stream (Şen et al., 2014). It has been observed that $C$. kosswigi population reproduced at similar periods from various regions in Lake Van Basin 
Atıcı et al., Ege Journal of Fisheries and Aquatic Sciences, 38(3), 293-302 (2021)

Table 9. Population characteristics of Capoeta kosswigi genus presented different studies in Lake Van Basin

\begin{tabular}{|c|c|c|c|c|c|c|c|c|c|c|c|c|c|c|}
\hline Locality & Species* & $\mathrm{N}$ & $M$ & $F$ & J & M:F & $\begin{array}{l}\mathrm{FL} \\
(\min - \\
\max )\end{array}$ & $\begin{array}{l}W \\
(\min - \\
\max )\end{array}$ & a & b & $r^{2}$ & $\begin{array}{l}\text { Mean K } \\
(\min - \\
\max )\end{array}$ & $\begin{array}{l}\text { GSI } \\
\text { (min- } \\
\text { max) }\end{array}$ & Reference \\
\hline $\begin{array}{l}\text { Deliçay } \\
\text { Stream }\end{array}$ & C. kosswigi & 309 & 113 & 17 & 179 & $1: 0.15$ & $\begin{array}{l}3.7- \\
26.1\end{array}$ & $\begin{array}{l}0.6- \\
227.4\end{array}$ & 0.01435 & 2.952 & 0.996 & $\begin{array}{l}1.305 \\
(0.798- \\
1.886)\end{array}$ & $\begin{array}{l}0.39- \\
16.00\end{array}$ & $\begin{array}{l}\text { The present } \\
\text { study }\end{array}$ \\
\hline Nazik Lake & C. capoeta & 603 & 331 & 254 & 18 & 1:0.77 & $\begin{array}{l}1.9- \\
48.3\end{array}$ & $\begin{array}{l}0.1- \\
1379.5\end{array}$ & 0.01349 & 2.960 & 0.993 & $\begin{array}{l}1.234 \\
(0.494- \\
1.514)\end{array}$ & $\begin{array}{l}1.16- \\
8.65\end{array}$ & $\begin{array}{l}\text { Şen et al. } \\
(1999)\end{array}$ \\
\hline $\begin{array}{l}\text { Koçköprü } \\
\text { Dam Lake }\end{array}$ & C. capoeta & 1234 & 507 & 727 & - & $1: 1.43$ & $\begin{array}{l}3.2- \\
39.8\end{array}$ & $\begin{array}{l}0.4- \\
755.6\end{array}$ & 0.01262 & 2.999 & 0.998 & $\begin{array}{l}1.275 \\
(1.078- \\
1.434)\end{array}$ & $\begin{array}{l}1.05- \\
10.10\end{array}$ & $\begin{array}{l}\text { Elp and } \\
\text { Karabatak } \\
(2007)\end{array}$ \\
\hline $\begin{array}{l}\text { Zernek Dam } \\
\text { Lake }\end{array}$ & C. capoeta & 586 & 158 & 272 & 156 & $1: 1.72$ & $4-41$ & $\begin{array}{l}0.7- \\
1060.4\end{array}$ & 0.0137 & 2.992 & 0.990 & $\begin{array}{l}1.314 \\
(0.997- \\
1.793)\end{array}$ & $\begin{array}{l}0.23- \\
7.85\end{array}$ & $\begin{array}{l}\text { Sen et al. } \\
(2008)\end{array}$ \\
\hline $\begin{array}{l}\text { Karasu } \\
\text { Stream }\end{array}$ & C. capoeta & 427 & 216 & 183 & 28 & $1: 0.85$ & $4-37.5$ & $\begin{array}{l}0.7- \\
676.2\end{array}$ & 0.0129 & 3.039 & 0.989 & $\begin{array}{l}1.452 \\
(1.069- \\
2.135)\end{array}$ & - & $\begin{array}{l}\text { Elp and Şen } \\
(2009)\end{array}$ \\
\hline $\begin{array}{l}\text { Çığlı } \\
\text { Stream }\end{array}$ & C. capoeta & 535 & 254 & 196 & 85 & 1:0.77 & $\begin{array}{l}3.8- \\
33.2\end{array}$ & $\begin{array}{l}0.8- \\
432.3\end{array}$ & 0.0170 & 2.887 & 0.985 & $\begin{array}{l}1.280 \\
(0.665- \\
1.866)\end{array}$ & $\begin{array}{l}1.33- \\
11.33\end{array}$ & $\begin{array}{l}\text { Şen et al. } \\
(2014)\end{array}$ \\
\hline
\end{tabular}

*In binomial nomenclature, C. capoeta was used as the synonym of C. kosswigi.

The maximum size for $B$. ercisianus was found as 22.7 $\mathrm{cm}$ and $140.0 \mathrm{~g}$. These values are very higher than Çığı Stream (Table 10). Bilici et al. (2017) explained the size differences in the populations with the selectivity of the sampling nets used, fishing pressure and moreover, ecological differences between lakes and streams. In Deliçay Stream, weight increased isometric with size since the values of $b$ had not a significant difference from the value 3.0 $(p>0.05)$. The regression equation for length-weight relationship of $B$. ercisianus shows that the species exhibited an isometric growth pattern. This indicates that there was dimensional proportionality (in body weight and total length) at the same rate. Froese (2006) reported that if $b=3$, then small number of specimens in the fish sample have the same form and condition as large specimens. The $b$ value in our study is similar to the value reported for Koçköprü Dam Lake and Çığı Stream (Table 10). According to their results, the growth type of population was isometric in Çığı Stream.

The mean Fulton's condition factor values for $B$. ercisianus in present study were lower than Koçköprü Dam Lake and Çığlı Stream (Table 10). In present study, the highest value was reached in May, being higher in the feding months and just prior to spawning. These results were similar with Koçköprü Dam Lake and Çığıı Stream.

The sex ratio of male to female for $B$. ercisianus was 1:0.64 and the difference was statistically significant $\left(X^{2}=\right.$ $12.30, p<0.05)$. In other studies, the male:female ratio has been presented in Table 10. The similar studies showed that the males were dominant. Generally, it is reported that the ability of males to hatch is higher than females in freshwater, but the proportion of males gradually decreases in the upper age classes and the proportion of females becomes quiet dominant in a population (Yıldırım et al., 2001).
The first sexual maturity size for $B$. ercisianus individuals in Deliçay was observed at $9 \mathrm{~cm}$ in males, and $12 \mathrm{~cm}$ in females. It was reported as $7.0-7.9 \mathrm{~cm}$ for males and 15.0 $15.9 \mathrm{~cm}$ for females from Koçköprü Dam Lake (Elp et al., 2006) and $6.0-6.9 \mathrm{~cm}$ for males and $10.0-10.9 \mathrm{~cm}$ for females from Çığlı Stream (Şen and Kara, 2016). Our results were close to the values reported for Koçköprü Dam Lake and Çığlı Stream. Moreover, males may grow slower than the females or males may mature earlier than the females in Lake Van Basin.

The GSI peak for $B$. ercisianus was observed on May $(6.877 \pm 1.084)$, whereas the lowest GSI was in August $(1.429 \pm 0.091)$. Spawning took place intensively from 1 st week of May to $1^{\text {st }}$ week of August. Şen and Kara (2016) determined that spawning period for $B$. ercisianus was happened between May and August in Çığı Stream. The results of the present study are similar to the results given for B. ercisianus population in Çığlı Stream.

In conclusion, from these measurements and calculations, it can be argued that growth and condition in the population had suitable values. It was established that $C$. kosswigi attained sexual maturity when they reached to $11 \mathrm{~cm}(100 \%)$ for males and $18 \mathrm{~cm}(100.0 \%)$ for females. The individuals maturation for $B$. ercisianus occurred at $9 \mathrm{~cm}(85.7 \%)$ for males and $12 \mathrm{~cm}(100.0 \%)$ for females. The spawning period for $C$. kosswigi was observed from $1^{\text {st }}$ week of May to $2^{\text {nd }}$ week of July, and for $B$. ercisianus from $1^{\text {st }}$ week of May to $1^{\text {st }}$ week of August. It is expected that the results of the presently reported study will contribute to the sustainable fishery for $C$. kosswigi and $B$. ercisianus in the Deliçay Stream. It may be suggested that fishing should be forbidden between April and August and minimum catching size must be $20 \mathrm{~cm}$ fork length for $C$. kosswigi and $15 \mathrm{~cm}$ fork length for $B$. ercisianus. 
Table 10. Population characteristics of Barbus ercisianus presented different studies

\begin{tabular}{|c|c|c|c|c|c|c|c|c|c|c|c|c|c|c|}
\hline Locality & Species* & $\mathbf{N}$ & M & $F$ & $\mathrm{~J}$ & $M: F$ & $\begin{array}{l}\text { FL } \\
(\min - \\
\max )\end{array}$ & $\begin{array}{l}\text { W } \\
\text { (min-max) }\end{array}$ & a & b & $r^{2}$ & $\begin{array}{l}\text { Mean K } \\
\text { (min- } \\
\text { max) }\end{array}$ & GSI & Reference \\
\hline $\begin{array}{l}\text { Deliçay } \\
\text { Stream }\end{array}$ & B. ercisianus & 288 & 145 & 92 & 51 & $1: 0.64$ & $4.3-22.7$ & $1.2-140.0$ & 0.01276 & 2.959 & 0.994 & $\begin{array}{l}1.158 \\
(0.864- \\
1.559)\end{array}$ & 4.184 & $\begin{array}{l}\text { The } \\
\text { present } \\
\text { study }\end{array}$ \\
\hline $\begin{array}{l}\text { Koçköprü } \\
\text { Dam Lake }\end{array}$ & B. ercisianus & 204 & 85 & 68 & 51 & $1: 0.80$ & $3-33.8$ & $0.1-428$ & 0.014 & 2.934 & 0.992 & $\begin{array}{l}1.242 \\
(0.790- \\
2.226)\end{array}$ & - & $\begin{array}{l}\text { Elp et al. } \\
(2006)\end{array}$ \\
\hline $\begin{array}{l}\text { Çığlı } \\
\text { Stream }\end{array}$ & B. plebejus & 196 & 119 & 76 & 1 & $1: 0.64$ & $4.3-16.6$ & $1.2-65.8$ & 0.0146 & 2.934 & 0.976 & $\begin{array}{l}1.260 \\
(0.954- \\
1.632)\end{array}$ & $\begin{array}{l}1.71- \\
10.03\end{array}$ & $\begin{array}{l}\text { Şen and } \\
\text { Kara } \\
(2016)\end{array}$ \\
\hline
\end{tabular}

${ }^{*}$ In binomial nomenclature, $B$. plebejus was used as the synonym of $B$. ercisianus.

\section{ACKNOWLEDGEMENTS}

This study was financially supported by Van Yüzüncü Yıl University Scientific Research Projects Coordination Department (No. 2015-FBE-YL353).

\section{REFERENCES}

Abobi, S.M. (2015). Weight-length models and relative condition factors of nine (9) freshwater fish species from the Yapei stretch of the White Volta, Ghana. Elixir Applied Zoology, 79, 30427-30431.

Bagenal, T.B. \& Tesch, F.W. (1978). Age and growth. In T.B. Bagenal, (Ed.) Fish Production in Freshwater (pp. 120-128). London: Oxford.

Bilici, S., Çiçek, T. \& Ünlü, E. (2017). Observation on the age, growth and somatic condition of Carasobarbus luteus (Heckel, 1843) and Capoeta trutta (Heckel, 1843) (Cyprinidae) in the Tigris River, Turkey. Iranian Journal of Fisheries Sciences, 16(1), 170-187.

Bogler, T. \& Connolly, P.L. (1989). The selection of suitable indices for the measurement and analysis of fish condition. Journal of Fish Biology, 34(2), 171-182. DOI: 10.1111/j.1095-8649.1989.tb03300.x

Çetinkaya, O. (1993). Van Gölü Havzası Su Kaynakları ve Balıkçılık Potansiyeli. Doğu Anadolu Bölgesi I. Su Ürünleri Sempozyumu 1993 (s. 71-83). Erzurum, Turkey: Bildiriler Kitabı.

Çetinkaya, O., Şen, F. \& Elp, M. (2005). Balıklarda büyüme ve büyüme analizleri. In M. Karataş, (Ed.) Balık Biyolojisi Araştırma Yöntemleri (pp. 93-120). Ankara: Nobel Publisher.

Crim, W.L. \& Glebe, B.D. (1990). Reproduction. In C.B. Schreck and P.B. Moyle (Ed.), Methods for Fish Biology (pp. 529-553). Bethesda: American Fisheries Society.

Elp, M., Çetinkaya, O., Kankaya, E., Şen, F. \& Ünal, G. (2006). A study of the some growth parameters of barbel (Barbus plebejus ercisianus, Karaman 1971) living in the Koçköprü dam lake basin. Journal of Biological Sciences, 6(4), 775-780. DOI: 10.3923/jbs.2006.775.780

Elp, M. \& Karabatak, M. (2007). A study on Capoeta capoeta (Guldenstaedt, 1773) population living in Koçköprü Dam Lake; Van-Turkey. Journal of Applied Biology Science, 1(2), 57-62.

Elp, M. \& Şen, F. (2009). Biological properties of Capoeta capoeta (Guldenstaedt, 1773) population living in Karasu Stream (Van, Turkey). Journal of Animal and Veterinary Advances, 8(1), 139-142.

Elp, M., Atıcı, A.A., Şen, F. \& Duyar, H.A. (2016). Distribution of fish species in the Van Lake Basin (in Turkish with English abstract). Yüzüncü Yıl University Journal of Agricultural Science, 26(4), 563-568. DOI: $10.29133 / y y u t b d .282808$

Elp, M. (2017). Determination of genetic variation of population of Capoeta (Cyprinidae) by the RFLP method in Van Lake Basin (in Turkish with English abstract). Menba Journal of Fisheries Faculty, 3(1-2), 17-23.
The research detailed above was approved by Van Yüzüncü Yıl University Animal and Researches Local Ethic Committee in the session held on 05/11/2015 and 26/07/2018 (decision number 2015/12 and 2018/07).

Froese, R. (2006). Cube law, condition factor and weight-length relationships: history, meta-analysis and recommendations. Journal of Applied Ichthyology, 22, 241-253. DOI: 10.1111/j.1439-0426.2006.00805.x

Froese, R., Tsikliras, A.C. \& Stergiou, K.I. (2011). Editorial note on weightlength relations of fishes. Acta Ichthyologica et Piscatoria, 41(4), 261263. DOI: 10.3750/AIP2011.41.4.01

Geldiay, R. \& Balık, S. (2009). Türkiye Tatısu Balıkları. VI. Baskı, İzmir: Ege University Faculty of Fisheries Publisher.

Haimovici, M. \& Velasco, G. (2000). Length-weight relationship of marine fishes from southern Brazil. The ICLARM Quarterly, 23(1), 14-16. DOI: $10.2307 / 1540$

Karaman, M. (1969). Revision der Kleinasiatischen und Vorderasias und Nordafrikas. Mitt. Hamburg Zool. Mus. Inst. Band., 67, 175-254.

Karaman, M.S. (1971). Süsswasserfische der Türkei, 8. Teil: Revision der Barben Europas, Vorderasien und Nordafrika. Mitt. Hamburg. Zool. Mus. Inst. Band., 67, 175-254.

Karataş, M., Başusta, N. \& Gökçe, M.A. (2005). Balıklarda üreme. In M. Karataş, (Ed.) Balık Biyolojisi Araştırma Yöntemleri (pp. 63-97). Ankara: Nobel Publisher.

Kimmerer, W., Avent S.E. \& Bollens, S.M. (2005). Variability in length-weight relationships used to estimate biomass of estuarine fish from survey data. Transactions of the American Fisheries Society, 134, 481-495. DOI:10.1577/T04-042.1

Le Cren, E.D. (1951). The Length-weight relationship and seasonal cycle in gonad weight and condition in the perch (Perca fluviatilis). Journal of Animal Ecology, 20(2), 201-219. DOI: 10.2307/1540

Nikolsky, G.V. (1963). The Ecology of Fishes. London and New York: Academic Press.

Pajuelo, J. G. \& Lorenzo, J. M. (1998). Population biology of common pandora Pagellus erythrinus (Pisces: Sparidae) of the Canary Islands. Fisheries Research 36, 75-86. DOI: 10.1016/S0165-7836(98)00110-6

Ricker, W.E. (1975). Computation and interpretation of biological statistics of fish populations. Bulletin of the Fisheries Research Board of Canada, 191, 1-382.

Sakar, U.K., Kahn, G.E., Dabas, A., Pathak, A.K., Mir, J.I., Rebello, S.C., Pal, A. \& Singh, S.P. (2013). Length weight relationship and condition factor of selected freshwater fish species found in river Ganga, Gomti and Rapti, India. Journal of Environmental Biology, 34(5), 951-956. 
Şen, F., Çetinkaya, O. \& Elp, M. (1999). A research on the population of Nazik Lake (Ahlat-Bitlis) Capoeta kosswigi (Capoeta capoeta, G., 1773). X. National Fisheries Symposium 1999 (pp. 465-475). Adana, Turkey: Bildiriler Kitabı.

Şen, F., Elp, M. \& Kankaya, E. (2008). Growth and reproduction of Capoeta capoeta (Guldenstaedt, 1772) in Zernek Dam Lake Van, Turkey. Journal of Animal and Veterinary Advances, 7(10), 1267-1272.

Şen, F., Elp, M. \& Kara, O. (2014). Population structure, growth and reproduction properties of Capoeta capoeta (Guldenstaedt, 1772) Living in Çı̆̆ı (Zapbaşı) Stream, Van, Turkey. Journal of Animal and Veterinary Advances, 13(3), 119-122.

Şen, F. \& Kara, O. (2016). Population structure, growth and reproduction properties of barbel (Barbus plebejus Bonaparte, 1832) living in Çığlı stream, Van, Turkey. Iranian Journal of Fisheries Sciences, 15(2), 827838.

Şen, F., Atıcl, A.A. \& Elp, M. (2018). Endemic fish species of Van Lake Basin (in Turkish with English abstract). Yüzüncü Yıl University Journal of Agricultural Sciences, 28, 63-70.
Türkmen, M., Erdoğan, O., Yıldırım, A. \& Akyurt, I. (2002). Reproduction tactics, age and growth of C. C. umbla Heckel. 1843 from the Askale Region of the Karasu River, Turkey. Fisheries Research, 54(3), 317328. DOI: 10.1016/S0165-7836(01)00266-1

Wootton, R.J. (1992). Fish Ecology. Scotland: Thomson Litho Ltd.

Wootton, R.J. (1998). Ecology of teleost fishes. Dordrecht: Kluwer Academic Publishers.

Yıldırım, A., Erdoğan, O. \& Türkmen, M. (2001). On the age, growth and reproduction of the barbel, Barbus plebejus escherichi (Steindachner, 1897) in the Oltu Stream of Çoruh River (Artvin-Turkey). Turkish Journal of Zoology, 25(2), 163-168.

Yılmaz, M., Gül, A. \& Solak, K. (2003). Growh performance of Capoeta capoeta umbla (Heckel, 1843) living in the region between Sivas and Erzincan of Upper Euphrates (in Turkish with English abstract). Gazi Üniversitesi Gazi Eğitim Fakültesi Dergisi, 23(2), 23-40.

Zar, J. H. (1999). Biostatistical analysis. USA: Prentice Hall. 